\title{
Preoperative Chemoradiation in Locally-Advanced Resectable Carcinoma of the Esophagus in a Single Rural Cancer Hospital in Western India
}

\author{
Yogesh S. Anap ${ }^{1}$ Prasad K. Tanawade ${ }^{1}$ Manish J. Mathankar ${ }^{1} \quad$ Ashwini D. Mane-Patil $^{2}$ \\ Kiran G. Bagul ${ }^{3}$ Reshma S. Pawar ${ }^{3}$ Suraj B. Pawar ${ }^{3}$
}

${ }^{1}$ Department of Radiation Oncology, Kolhapur Cancer Centre, Karveer, Maharashtra, India

2Department of Pathology, Kolhapur Cancer Centre, Karveer, Maharashtra, India

${ }^{3}$ Department of Surgical Oncology, Kolhapur Cancer Centre, Karveer, Maharashtra, India

\begin{abstract}
Address for correspondence Dr. Yogesh S. Anap, MD, DNB, MNAMS, Department of Radiation Oncology, Kolhapur Cancer Centre, Karveer 416234, Maharashtra, India (e-mail: yogesh.anap1@gmail.com).
\end{abstract}

South Asian J Cancer 2020;9:158-162.

\section{Abstract}

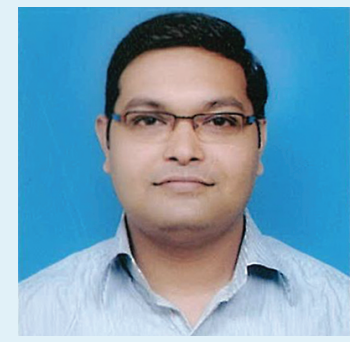

Dr. Yogesh S. Anap, MD, DNB, MNAMS

Keywords

- esophageal cancer

- neoadjuvant

chemoradiation

- rural cancer hospital
Background The current standard of care for the treatment of surgically resectable carcinoma of the esophagus is preoperative chemoradiation followed by surgery. There is strong evidence that this trimodality approach improves survival as compared with surgery alone.

Objective The objective of this study is to determine the feasibility of this approach in a rural cancer institute in western India.

Materials and Methods The data of all the 157 consecutively treated patients with locally-advanced carcinoma of the esophagus from March 2013 to March 2017 who were started on preoperative chemoradiation were analyzed retrospectively.

Results Of the 157 patients who were started on preoperative chemoradiation, 68 patients underwent surgery. There are various practical reasons for not undergoing the definitive surgery, with the important being the socioeconomic support to the patients during the course of treatment.

Conclusion This study gave us insight into the strategic selection of patients for the trimodality approach as well as the need for continuous socioeconomic support throughout the treatment course.

\section{Introduction}

Esophageal carcinoma has the poor prognosis in spite of the advancement in treatment modalities. The incidence of newly diagnosed cases of carcinoma of the esophagus worldwide per year is 572,034 , while the mortality is 508,585 . The corresponding figures of India are 52,396 and 46,504, respectively. ${ }^{1}$ The treatment has evolved from single modality to multimodality approach over the past few decades.
Conventionally, esophagectomy has been the main choice of treatment for resectable middle and lower-third esophageal cancers. The trimodality approaches involving neoadjuvant chemoradiotherapy (NACRT) followed by surgery for resectable middle and lower-third esophageal cancer have been studied. ${ }^{2}$ The feasibility of this combination treatment needs to be evaluated in developing countries, especially in the rural background. Here, we present an audit of the retrospective
How to cite this article: Anap YS, Tanawade PK, Mathankar MJ, Mane-Patil AD, Bagul KG, Pawar RS, Pawar SB. Preoperative Chemoradiation in Locally-Advanced Resectable Carcinoma of the Esophagus in a Single Rural Cancer Hospital in Western India. South Asian J Cancer 2020;9(3):158-162.

DOI https://doi.org/10.1055/s-0041-1723075 ISSN 2278-330X.

\section{(c) 2020. MedIntel Services Pvt Ltd.}

This is an open access article published by Thieme under the terms of the Creative Commons Attribution-NonDerivative-NonCommercial-License, permitting copying and reproduction so long as the original work is given appropriate credit. Contents may not be used for commercial purposes, or adapted, remixed, transformed or built upon. (https://creativecommons.org/licenses/by-nc-nd/4.0/)

Thieme Medical and Scientific Publishers Pvt. Ltd., A-12, 2nd Floor, Sector 2, Noida-201301 UP, India 
analysis of prospectively maintained data of such combination treatment practiced in a single rural cancer center in Western India.

\section{Materials and Methods}

This is a retrospective study of 157 consecutive patients diagnosed with nonmetastatic carcinoma of the esophagus, and who were treated in a single cancer institute in rural Western India from March 2013 to March 2017. All case records and electronic data were retrieved and analyzed. All patients underwent endoscopic evaluation of the upper gastrointestinal tract (GIT). The disease was documented, and biopsies were collected. Patients underwent staging investigations with contrast-enhanced computed tomography (CT) scan of the neck, thorax and upper abdomen, and hematological counts for determining fitness for chemotherapy. All histology proven, treatment naïve cases of carcinoma of the middle and lower-third esophagus were included in the study. Histology other than squamous carcinoma and adenocarcinoma were excluded from the study. Patients with only localized disease with or without regional nodes were included. Patients with performance status 0,1 , and 2 and who would complete the intended neoadjuvant treatment were included for the treatment. All the patients carried out discussions with the surgical oncologist, radiation oncologist, and medical oncologist before initiating the treatment.

\section{Treatment Details \\ Radiotherapy}

The patient underwent neoadjuvant external radiotherapy to primary and regional nodes, with the help of photons, by conformal techniques such as either three-dimensional conformal radiation therapy (3DCRT) or intensity-modulated radiation therapy (IMRT) at doses of $41.4 \mathrm{~Gy}$ to $45 \mathrm{~Gy}$ in conventional fractionation over the duration of 5 weeks.

\section{Chemotherapy}

Patients received concomitant chemotherapy maximum of five cycles after ensuring adequate hematological and renal functions along with radiotherapy. The drugs received were either paclitaxel $\left(50 \mathrm{mg} / \mathrm{m}^{2}\right)$ with carboplatin (area under the curve $=2)$, cisplatin $\left(30 \mathrm{mg} / \mathrm{m}^{2}\right)$ with 5 fluorouracil $\left(500 \mathrm{mg} / \mathrm{m}^{2}\right)$, cisplatin $\left(30 \mathrm{mg} / \mathrm{m}^{2}\right)$ alone, or capecitabine $\left(825 \mathrm{mg} / \mathrm{m}^{2} \mathrm{BD}\right)$ alone. The choice of chemotherapy was at the discretion of the treating oncologist.

\section{Response Evaluation}

Response to NACRT was evaluated with contrast-enhanced CT scan 4 to 5 weeks after NACRT, with response evaluation criteria in solid tumor criteria. Patients having complete response, partial response, or stable disease were evaluated for surgery. Patients with progression of disease underwent salvage treatment at the discretion of treating physician. Salvage treatment consisted of either completion of radiotherapy, chemotherapy, or best supportive care.

\section{Surgery}

Patients underwent esophagectomy, either open or thoracoscopic, 4 to 6 weeks after NACRT. All complications of surgery and histopathology were documented.

\section{Follow-up and Evaluation}

Patients were followed-up every 3 months for initial 2 years after completion of treatment and later at every 6 months. Disease status at each follow-up was documented.

\section{Statistical Analysis}

SPSS software version 21 was used for statistical analysis. Survival was calculated using the Kaplan-Meier method. Overall survival (OS) was calculated from the date of registration to the last date of follow-up or death. Disease-free survival was calculated from the date of surgery to the date of recurrence of the disease.

\section{Results}

One hundred and fifty-seven patients were started on NACRT. The demographic details were captured for all patients (-Table 1). The details of radiation therapy, chemotherapy, and surgery were documented ( $>$ Table 2 ). An effort was made to find the causes of default after neoadjuvant therapy through either telephonic contact with the patient or personal home visit by the hospital representative. The treatment-related toxicities and survival were captured (- Tables 3 and 4).

Table 1 Demography

\begin{tabular}{|c|c|c|}
\hline Characteristics & Value & Absolute (\%) \\
\hline Study duration & March 2013-March 2017 & \\
\hline Number of patients & 157 & \\
\hline $\begin{array}{l}\text { Age (years), } \\
\text { median (range) }\end{array}$ & $55(30-81)$ & \\
\hline \multirow[t]{2}{*}{ Gender } & Male & $82(52)$ \\
\hline & Female & $75(48)$ \\
\hline \multirow[t]{2}{*}{ Category } & Private & $27(17)$ \\
\hline & Scheme & $130(83)$ \\
\hline \multirow[t]{2}{*}{ Comorbidities } & Nil & $107(68)$ \\
\hline & One or more & $50(32)$ \\
\hline \multirow[t]{2}{*}{ Addictions } & Nil & $62(40)$ \\
\hline & One or more & $95(60)$ \\
\hline \multirow[t]{2}{*}{ Site } & Middle third & $69(44)$ \\
\hline & Lower third & $88(56)$ \\
\hline \multirow[t]{2}{*}{ Histology } & Squamous carcinoma & $136(87)$ \\
\hline & Adenocarcinoma & $21(13)$ \\
\hline \multirow[t]{2}{*}{ T stage } & $\mathrm{T} 2$ & $5(3)$ \\
\hline & $\mathrm{T} 3$ & $152(97)$ \\
\hline \multirow[t]{3}{*}{$\mathrm{N}$ stage } & No & $52(33)$ \\
\hline & N1 & $85(54)$ \\
\hline & $\mathrm{N} 2$ & $20(13)$ \\
\hline
\end{tabular}


Table 2 Treatment details

\begin{tabular}{|c|c|c|}
\hline Treatment details & $\begin{array}{l}\text { Absolute } \\
\text { number }\end{array}$ & Percentage \\
\hline \multicolumn{3}{|l|}{ NART dose } \\
\hline $45 \mathrm{~Gy} / 25^{\#}$ & 136 & 87 \\
\hline $41.4 \mathrm{~Gy} / 21^{\#}$ & 7 & 5 \\
\hline \multicolumn{3}{|l|}{ NART technique } \\
\hline 3DCRT & 67 & 43 \\
\hline IMRT & 90 & 57 \\
\hline \multicolumn{3}{|l|}{ NART breaks } \\
\hline Yes & 17 & 11 \\
\hline No & 140 & 89 \\
\hline \multicolumn{3}{|l|}{$\begin{array}{l}\text { Reasons for NART } \\
\text { breaks }\end{array}$} \\
\hline $\begin{array}{l}\text { Machine } \\
\text { breakdown }\end{array}$ & 4 & \multirow[t]{4}{*}{-} \\
\hline Death & 2 & \\
\hline Toxicity & 1 & \\
\hline Default & 10 & \\
\hline \multicolumn{3}{|l|}{ Concomitant CT given } \\
\hline Yes & 141 & 90 \\
\hline No & 16 & 10 \\
\hline \multicolumn{3}{|l|}{$\begin{array}{l}\text { Reason concomitant CT } \\
\text { not given }\end{array}$} \\
\hline Death & 2 & \multirow[t]{3}{*}{-} \\
\hline Unfit & 2 & \\
\hline Financial & 12 & \\
\hline \multicolumn{3}{|l|}{ Concomitant CT drugs } \\
\hline$P+C$ & 100 & \multirow[t]{4}{*}{-} \\
\hline 5 FU + cisplatin & 16 & \\
\hline Cisplatin & 3 & \\
\hline Capecitabine & 22 & \\
\hline $\begin{array}{l}\text { Number of concomi- } \\
\text { tant CT cycles, median }\end{array}$ & 5 & - \\
\hline \multicolumn{3}{|l|}{ Concomitant CT breaks } \\
\hline Yes & 50 & \multirow[t]{2}{*}{-} \\
\hline No & 91 & \\
\hline \multicolumn{3}{|l|}{$\begin{array}{l}\text { Concomitant CT breaks } \\
\text { reasons }\end{array}$} \\
\hline Toxicity & 41 & \multirow[t]{4}{*}{-} \\
\hline Fitness & 2 & \\
\hline Financial & 6 & \\
\hline $\begin{array}{l}\text { Communication } \\
\text { gap }\end{array}$ & 1 & \\
\hline \multicolumn{3}{|l|}{ Response CT scan done } \\
\hline Yes & 124 & \multirow[t]{2}{*}{-} \\
\hline No & 33 & \\
\hline $\begin{array}{l}\text { Radiological response } \\
\text { to NACRT }\end{array}$ & & \\
\hline
\end{tabular}

(Continued)
Table 2 (Continued)

\begin{tabular}{|c|c|c|}
\hline Treatment details & $\begin{array}{l}\text { Absolute } \\
\text { numbers }\end{array}$ & Percentage \\
\hline Complete response & 1 & \\
\hline Partial response & 86 & \\
\hline Stable disease & 16 & \\
\hline Progressive disease & 21 & \\
\hline \multicolumn{3}{|l|}{ Surgery done } \\
\hline Yes & 68 & $43 \%$ \\
\hline No & 89 & $57 \%$ \\
\hline \multicolumn{3}{|l|}{ Reasons for no surgery } \\
\hline PD & 20 & \multirow[t]{8}{*}{-} \\
\hline Financial & 39 & \\
\hline Social & 6 & \\
\hline $\begin{array}{l}\text { Asymptomatic } \\
\text { (patient's decision) }\end{array}$ & 9 & \\
\hline Unfit & 6 & \\
\hline Death & 5 & \\
\hline $\begin{array}{l}\text { Unwilling for } \\
\text { surgery }\end{array}$ & 3 & \\
\hline Second primary & 1 & \\
\hline \multicolumn{3}{|l|}{$\begin{array}{l}\text { Duration between RT } \\
\text { completion and surgery } \\
\text { (days), median (range) }\end{array}$} \\
\hline $49(33-316)$ & & - \\
\hline \multicolumn{3}{|l|}{ Surgery type } \\
\hline $\begin{array}{l}\text { Thoracoscopic } \\
\text { esophagectomy } \\
\text { with 2-field } \\
\text { lymphadenectomy }\end{array}$ & 36 & \multirow[t]{5}{*}{-} \\
\hline $\begin{array}{l}\text { Thoracoscopic } \\
\text { esophagectomy } \\
\text { with 3-field } \\
\text { lymphadenectomy }\end{array}$ & 6 & \\
\hline $\begin{array}{l}\text { Transthoracic } \\
\text { esophagectomy } \\
\text { with 2-field } \\
\text { lymphadenectomy }\end{array}$ & 9 & \\
\hline $\begin{array}{l}\text { Transthoracic } \\
\text { esophagectomy } \\
\text { with 3-field } \\
\text { lymphadenectomy }\end{array}$ & 8 & \\
\hline $\begin{array}{l}\text { Transhiatal } \\
\text { esophagectomy }\end{array}$ & 9 & \\
\hline
\end{tabular}

Abbreviations: 3DCRT, three-dimensional conformal radiation therapy; $\mathrm{CT}$, computed tomography; FU, fluorouracil; IMRT, Intensity-modulated radiation therapy; NART, neoadjuvant radiotherapy; NACRT, neoadjuvant chemoradiotherapy; PD, progression of disease RT, radiotherapy.

\section{Discussion}

The intention of this retrospective audit was to check the feasibility of NACRT followed by surgery in resectable carcinoma of the esophagus in a rural cancer center in western India. 
Table 3 Treatment-related toxicity details

\begin{tabular}{|c|c|c|}
\hline Toxicity & Absolute numbers & Percentage \\
\hline \multicolumn{3}{|l|}{ NART toxicity } \\
\hline \multicolumn{3}{|l|}{ Radiation dermatitis } \\
\hline Grade I & 108 & 69 \\
\hline Grade II & 49 & 31 \\
\hline Grade III-IV & 0 & 0 \\
\hline \multicolumn{3}{|l|}{ Esophagitis } \\
\hline Grade I & 84 & 54 \\
\hline Grade II & 62 & 39 \\
\hline Grade III & 11 & 7 \\
\hline \multicolumn{3}{|l|}{ CT toxicity (grade III) } \\
\hline Anemia & 1 & 0.7 \\
\hline Neutropenia & 7 & 5 \\
\hline Thrombocytopenia & 1 & 0.7 \\
\hline Renal & 15 & 11 \\
\hline \multicolumn{3}{|l|}{$\begin{array}{l}\text { Significant surgical } \\
\text { complications }\end{array}$} \\
\hline Pulmonary & 10 & 15 \\
\hline VC palsy & 8 & 12 \\
\hline Death & 6 & 9 \\
\hline Chyle leak & 6 & 9 \\
\hline Wound Infection & 2 & 3 \\
\hline
\end{tabular}

Abbreviations: CT, computed tomography; NART, neoadjuvant radiotherapy; VC, vocal cord.

Table 4 Treatment outcome

\begin{tabular}{|l|l|}
\hline Treatment outcome & Value number \\
\hline Pathological response after surgery (\%) & $27(40)$ \\
\hline \multicolumn{1}{|c|}{ Complete response } & $41(60)$ \\
\hline Partial response & $11(1-63)$ \\
\hline OS in all patients (157 patients), months & $18.5(3-63)$ \\
\hline $\begin{array}{l}\text { OS in patients who underwent surgery after } \\
\text { neoadjuvant therapy (68 patients), months }\end{array}$ & $8(1-35)$ \\
\hline $\begin{array}{l}\text { OS in patients who defaulted for surgery after } \\
\text { neoadjuvant treatment (89 patients), months }\end{array}$ & $20(3-63)$ \\
\hline $\begin{array}{l}\text { OS in patients who underwent surgery within } \\
60 \text { days of RT (51 patients), months }\end{array}$ & $17(4-52)$ \\
\hline $\begin{array}{l}\text { OS of patients who underwent surgery after } \\
60 \text { days of RT (17 patients), months }\end{array}$ & $16.5(3-62)$ \\
\hline $\begin{array}{l}\text { DFS in all patients in surgery group } \\
\text { (68 patients), months }\end{array}$ & $12(3-62)$ \\
\hline $\begin{array}{l}\text { DFS in complete response group } \\
\text { (27 months), months }\end{array}$ & $15(3-62)$ \\
\hline $\begin{array}{l}\text { DFS in partial response group (41 patients), } \\
\text { months }\end{array}$ & \\
\hline
\end{tabular}

Abbreviations: DFS, disease-free survival; OS, overall survival; RT, radiotherapy.

We neither aim to prove the efficacy of this approach nor do we question the efficacy of this approach in the rural setting.
We want to highlight the practical problems that we faced in the implementation of this approach and the reasons for noncompliance to the treatment.

NACRT was tolerated well by all the patients with acceptable toxicity profile. The surgical complication rates were acceptable and less than reported in the literature. ${ }^{2}$

The practice at our institute till 2013 was upfront surgical resection, followed by adjuvant treatment for resectable carcinoma of the esophagus. The landmark randomized trial published in 2012 showed a significant OS benefit of 49.4 months in trimodality treatment versus 24 months in surgery alone $\mathrm{arm}^{2}$ The "Evidence-Based Medicine Conference" conducted annually by the Tata Memorial Center, Mumbai, which discussed the guidelines for esophageal cancers in 2013 gave us the confidence to change our practice. We discussed the new strategy in our Institutional Review Board and started the new protocol from March 2013. Here, we present the retrospective audit of the patients afflicted with resectable carcinoma of the esophagus, and with curative intent, consecutively treated using NACRT. Fifty-six percent of the patients had carcinoma of the lower third of the esophagus; the most common histology was squamous cell carcinoma, in $87 \%$ of the patients, indicating squamous cell carcinoma is common histology even in the lower-third esophagus in our population. More than two-third of the patients were treated under one of the applicable government-sanctioned schemes, without any financial burden of the treatment on the patient or the family, but with certain limitations. The dose of radiotherapy for neoadjuvant setting in carcinoma of the esophagus varies in different randomized clinical trials. The range varies from $18.5 \mathrm{~Gy}$ to $50.4 \mathrm{~Gy}$ with different fractionation schedules. ${ }^{3-10}$ We implemented conventional fractionation schedules at doses of $41.4 \mathrm{~Gy}$ to $45 \mathrm{~Gy}$ with either 3DCRT or IMRT planning. The concomitant chemotherapy administered along with radiotherapy in neoadjuvant setting varies in different studies. The most commonly used drugs are cisplatin, 5 fluorouracil (5FU), paclitaxel, mitomycin, and etoposide.

Based on the CROSS trial results, we offered paclitaxel plus carboplatin regiment. However, due to financial reasons, this regimen was accepted by $72 \%$ of the patients. The rest received cisplatin or cisplatin with 5FU or capecitabine regimen. Sixteen patients received only neoadjuvant radiotherapy without concomitant chemotherapy, as they were unfit for chemotherapy. All the surgical specimens were reviewed by the single oncopathologist. There was no case with close or positive surgical cut margin in our group of patients. The pathological complete response rate was $40 \%$, which is comparable with the published literature. . $^{3-10}$

The OS of patients who underwent the trimodality treatment and those who defaulted for surgery after neoadjuvant treatment was 18.5 months and 8 months, respectively, showing the obvious benefit of the completion surgery ( $\rightarrow$ Fig. 1 ).

Out of 89 patients who did not complete the intended treatment, 45 patients could have completed their intended treatment, provided necessary intervening measures would have been taken such as financial support and social support. 


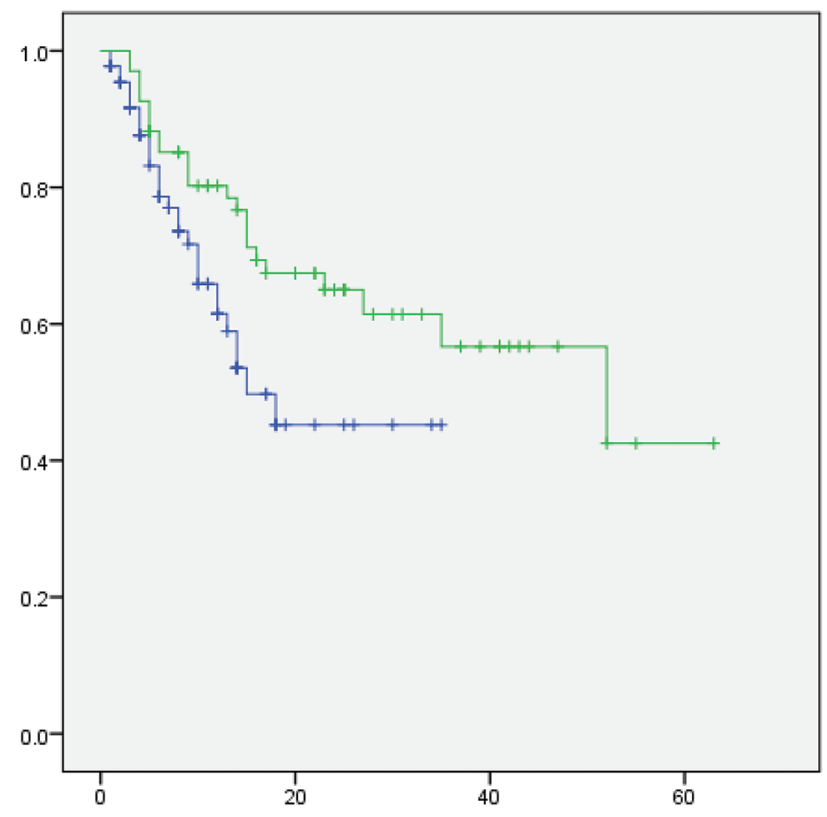

Fig. 1 Kaplan-Meier plot of overall survival. Green = patient receiving trimodality treatment; blue $=$ patients defaulted after neoadjuvant chemoradiotherapy (NACRT). $p=0.025$ (log-rank test).

The treating oncologist tried to contact all these patients through telephonic conversations or home visit by the representative. In spite of the treatment being partly or fully covered under government scheme, the priority of their daily wages prevented these patients from completing their treatment.

The next common reason for noncompliance was symptomatic relief due to neoadjuvant treatment in nine patients. Although the efforts were taken to stress the importance of surgery in spite of complete clinical benefit after neoadjuvant therapy, these patients never turned up for surgery.

Of the 20 patients who progressed after NACRT, 10 patients progressed at a distant site, while 10 patients progressed locally. These patients were advised palliative treatment or best supportive care.

This study gave us an insight into careful selection and counseling of the patients beforehand, ensuring lasting financial and social support through the course of the treatment in the rural setting in India. Interestingly, we found that the patients who underwent surgery within 60 days of completion of neoadjuvant treatment had a median overall survival of 20 months versus 17 months for those who came for surgery after 60 days. Majority of the delays in surgery was due to finances and logistics for surgery. This highlights the importance of adherence to the treatment schedule, especially after NACRT.

\section{Conclusion}

Our results for patients who completed the trimodality treatment are similar to those in the literature. However, the dropout rate after NACRT was a matter of concern. This study gave us insight into the fact that trimodality treatment is feasible in rural India, provided the strategic selection of the patients and continuous socioeconomic support through the course of the treatment is ensured.

\section{Financial Support and Sponsorship}

Nil.

\section{Conflicts of Interest}

None declared.

\section{References}

1 Bray F, Ferlay J, Soerjomataram I, Siegel RL, Torre LA, Jemal A. Global cancer statistics 2018: GLOBOCAN estimates of incidence and mortality worldwide for 36 cancers in 185 countries. CA Cancer J Clin 2018;68(6):394-424

2 Shapiro J, van Lanschot JJ, Hulshof MCC, et al; CROSS study group. Neoadjuvant chemoradiotherapy plus surgery versus surgery alone for oesophageal or junctional cancer (CROSS): long-term results of a randomised controlled trial. Lancet Oncol 2015;16(9):1090-1098

3 Urba SG, Orringer MB, Perez-Tamayo C, Bromberg J, Forastiere A. Concurrent preoperative chemotherapy and radiation therapy in localized esophageal adenocarcinoma. Cancer 1992; 69(2):285-291

4 Walsh TN, Noonan N, Hollywood D, Kelly A, Keeling N, Hennessy TP. A comparison of multimodal therapy and surgery for esophageal adenocarcinoma. N Engl J Med 1996;335(7):462-467

5 Bosset JF, Gignoux M, Triboulet JP, et al. Chemoradiotherapy followed by surgery compared with surgery alone in squamous-cell cancer of the esophagus. N Engl J Med 1997; 337(3):161-167

6 Burmeister BH, Smithers BM, Gebski V, et al; Trans-Tasman Radiation Oncology Group; Australasian Gastro-Intestinal Trials Group. Surgery alone versus chemoradiotherapy followed by surgery for resectable cancer of the oesophagus: a randomised controlled phase III trial. Lancet Oncol 2005;6(9):659-668

7 Tepper J, Krasna MJ, Niedzwiecki D, et al. Phase III trial of trimodality therapy with cisplatin, fluorouracil, radiotherapy, and surgery compared with surgery alone for esophageal cancer: CALGB 9781. J Clin Oncol 2008;26(7):1086-1092

8 Stahl M, Stuschke M, Lehmann N, et al. Chemoradiation with and without surgery in patients with locally advanced squamous cell carcinoma of the esophagus. J Clin Oncol 2005;23(10):2310-2317

9 Lee MS, Mamon HJ, Hong TS, etal.Preoperative cetuximab, irinotecan, cisplatin, and radiation therapy for patients with locally advanced esophageal cancer. Oncologist 2013;18(3):281-287

10 Krishnamurthy A, Mohanraj N, Radhakrishnan V, John A, Selvaluxmy G. Neoadjuvant chemoradiation for locally advanced resectable carcinoma of the esophagus: A singlecenter experience from India with a brief review of the literature. Indian J Cancer 2017;54(4):646-651 